\title{
Local Anesthetic Infiltration During Pediatric Percutaneous Nephrolithotomy Improves Postoperative Analgesia
}

\section{Çocuklarda Perkütan Nefrolitotomi Sırasında Uygulanan Lokal Anestezik Infiltrasyonunun Ameliyat Sonrası Analjezi Üzerine Etkisi}

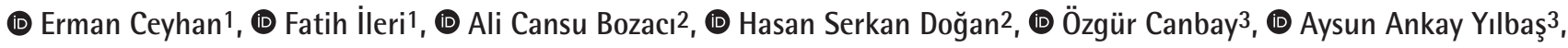 \\ (D) Serdar Tekgül2 \\ 1 Hacettepe University Faculty of Medicine, Department of Urology, Ankara, Turkiye \\ ${ }^{2}$ Hacettepe University Faculty of Medicine, Department of Urology, Division of Pediatric Urology, Ankara, Turkiye \\ ${ }^{3}$ Hacettepe University Faculty of Medicine, Department of Anesthesiology and Reanimation, Ankara, Turkiye
}

\section{What's known on the subject? and What does the study add?}

There is limited number of studies reporting pain management after pediatric percutaneous nephrolithotomy. Our study is the first to report the importance of preemptive local anesthetic use in pediatric percutaneous nephrolithotomy.

\begin{abstract}
Objective: Percutaneous nephrolithotomy is not pain-free due to the procedure itself and presence of post-operative diversion. Our purpose was to evaluate the efficacy of local anesthetic infiltration in postoperative analgesia in children who undergo percutaneous nephrolithotomy.

Materials and Methods: Forty-two renal units were included to our study. Local anesthesia group received prilocaine and bupivacaine injection through the percutaneous access line where patients received no local anesthetic constituted the control group. All patients received the same anesthesia protocol and $15 \mathrm{mg} / \mathrm{kg}$ paracetamol infusion postoperatively four times a day. Post-operative pain scores of patients were evaluated by using FLACC-FPS scales. Patients with pain scores $\geq 4$ received meperidine $1 \mathrm{mg} / \mathrm{kg}$ as rescue analgesic.

Results: Between the two groups there was no significant difference in pain scores except $24^{\text {th }}$ hour, where the local anesthesia group found to be favorable. The need $(p=0.040)$ and total number $(p=0.018)$ of rescue analgesic was significantly less in local anesthesia group. According to need for repetitive analgesic dose, the local anesthesia group was founded to be more advantageous $(p=0.017)$. The postoperative analgesic satisfaction of parents' was favorable in local anesthesia group ( $p=0.002)$.

Conclusion: In pediatric percutaneous nephrolithotomy, preemptive local anesthetic infiltration reduces postoperative pain, the need for analgesics, the number of analgesics used and also improves patient comfort and analgesic satisfaction.
\end{abstract}

Keywords: Percutaneous nephrolithotomy, Local anesthetic, Pain, Patient satisfaction with pain management

Öz

Amaç: Perkütan nefrolitotomi uygulama yolu ve ameliyat sonrasında diversiyon konulması sebebiyle ağrısız bir cerrahi değildir. Çalışmamızda perkütan nefrolitotomi uygulanan çocuk hastalarda lokal anestezik uygulamasının, ameliyat sonrası ağrıya etkisini araştırmak amaçlanmıştır.

Gereç ve Yöntem: Çalışmaya 42 renal ünite dahil edilmiştir. Lokal anestezik grubuna perkütan giriş hattı boyunca prilokain ve bupivakain enjeksiyonu yapılmıştır. Lokal anestezik uygulanmayan çocuklar kontrol gurubunu oluşturmuştur. Tüm hastalarda aynı anestezi protokolü kullanılmış olup ameliyat sonrası günde dört kez $15 \mathrm{mg} / \mathrm{kg}$ parasetamol infüzyonu uygulanmıştır. Ameliyat sonrası ağrı değerlendirmesi FLACC-FPS skorlamaları ile yapılmıştır. Ağrı skoru $\geq 4$ olan hastalara kurtarıcı analjezik olarak meperidine $1 \mathrm{mg} / \mathrm{kg}$ uygulanmıştır.

Bulgular: Gruplar arasında ağrı skorları açısından 24 saat dışında anlamlı fark saptanmamıştır. Lokal anestezik grubunda 24. saat ağrı skorları daha düşük bulunmuştur. Kurtarıcı analjezik intiyacının $(p=0,040)$ ve kullanılan toplam analjezik sayısının $(p=0,018)$ lokal anestezik grubunda anlamlı derecede az olduğu saptanmıştır. Tekrar eden analjezik ihtiyacı değerlendirildiğinde, lokal anestezik grubunun daha avantajlı olduğu görülmüştür

Correspondence: Erman Ceyhan MD, Hacettepe University Faculty of Medicine, Department of Urology, Ankara, Turkiye Phone: +90 5355873688 E-mail: erman_ceyhan@yahoo.com ORCID-ID: orcid.org/0000-0001-8223-6399

Received: 03.12.2018 Accepted: 16.02.2019

Cite this article as: Ceyhan E, İleri F, Bozacı AC, Doğan HS, Canbay Ö, Ankay Yılbaş A. Local Anesthetic Infiltration during Pediatric Percutaneous Nephrolithotomy Improves Postoperative Analgesia. J Urol Surg 2019;6(3):238-243.

๑Copyright 2019 by the Association of Urological Surgery / Journal of Urological Surgery published by Galenos Publishing House. 
$(p=0,017)$. Ebeveynlerin ameliyat sonrası analjezi memnuniyeti değerlendirildiğinde lokal anestezik grubunun daha avantajlı olduğu belirlenmiştir $(p=0,002)$.

Sonuç: Çocuk hastalarda perkütan nefrolitotomide uygulanan preemptif lokal anestezik uygulaması ameliyat sonrası ağrıyı, analjezik ihtiyacını ve uygulanan analjezik sayısını azaltır, hasta konforunu ve analjezik memnuniyetini artırır.

Anahtar Kelimeler: Perkütan nefrolitotomi, Lokal anestezik, Ağrı, Analjezi memnuniyeti

\section{Introduction}

Percutaneous nephrolithotomy (PCNL) is the preferred treatment option in whom the other minimally-invasive modalities failed or are inappropriate. Remarkable changes in PCNL technique have been made in order to reduce pain and minimize complications. Reduction of the sheath size led to minimallyinvasive approaches such as mini-PCNL, ultramini-PCNL and micro-PCNL (1). Then, the "tubeless" and "totally tubeless" PCNL emerged as methods promising less post-operative pain and faster recovery (2). However, standard PCNL with a nephrostomy tube is still the routine practice for adult and pediatric stone patients.

Post-operative pain management and patient comfort are also important in pediatric patients. To reduce post-operative pain, preemptive analgesia and multimodal protocols are used. Preemptive analgesia is described as analgesic administration before a painful stimulus. In this manner, local anesthetics (LAs) are widely used where they can block the sensation of pain before surgical incision, resulting less need for anesthetic drugs intra-operatively and less pain post-operatively (3). This multimodal approach increases the safety of general anesthesia and reduces the amount of drugs needed for general anesthesia as well as analgesic drugs including opioids (3). There are several studies on LA use in adult PCNL suggesting benefit but there is no study on pediatric population on this issue $(4,5)$.

Our purpose was to assess the effect of preemptive LA infiltration on postoperative analgesic need and patient comfort after pediatric PCNL.

\section{Materials and Methods}

The study was conducted after approval of the Hacettepe University Institutional Clinical Ethics Committee with the IRB number 16969557-331. A total of 42 renal units of 40 children who underwent PCNL between February 2015 and February 2017 were included in this study. One patient with neurological disorder and one patient with orthopedic disorder were excluded for that pain scoring would be misleading.

We constituted the control group of 21 cases who did not receive any LA before PCNL (control group, $\mathrm{n}=21$ ). The study group (LA group, $n=21$ ) was constituted by 21 patients who received LAs before PCNL. Prilocaine and bupivacaine mixture was used as
LAs in pediatric PCNL (2 mg/kg of $0.2 \%$ prilocaine and $2 \mathrm{mg} /$ $\mathrm{kg}$ of $0.5 \%$ bupivacaine). The LA group received prilocaine and bupivacaine at all layers through the access line (including skin, subcutaneous tissues, perirenal muscles and fascia) before the puncture. Surgeries were performed by the same surgeon (H.S.D.). All children were operated in the prone position with a standard pediatric PCNL approach via a $24 \mathrm{~F}$ sheath with a $17 \mathrm{~F}$ nephroscope by a single access made from the lower pole. After fragmentation with a pneumotic lithotripter, the stones were removed and a $14 \mathrm{~F}$ re-entry nephrostomy catheter was placed in each patient.

All patients received the same protocol for general anesthesia. The routine general anesthesia protocol for pediatric PCNL in our clinic is induction with $2.5 \mathrm{mg} / \mathrm{kg}$ propofol, $1 \mathrm{mcg} / \mathrm{kg}$ fentanyl, $0.6 \mathrm{mg} / \mathrm{kg}$ rocuronium and, for maintenance, $2 \%$ sevoflurane with remifentanil infusion. Remifentanil infusion is set to maintain blood pressure within $20 \%$ of baseline value. Ten minutes before the end of PCNL, remifentanil is stopped and, before 30 minutes, $15 \mathrm{mg} / \mathrm{kg}$ paracetamol infusion is started. We prefer routine paracetamol (4 times a day, $15 \mathrm{mg} /$ $\mathrm{kg}$ ) infusion for post-operative analgesia. None of the patients received non-steroid anti-inflammatory drugs (NSAIDs).

We routinely use the face, legs, activity, cry, consolability (FLACC) scale to assess post-operative pain in all pediatric patients and the Faces Pain Score-Revised (FPS-R) scale for children 8 years of age and older $(6,7)$. Post-operative pain assessment in children is done at post-operative $15^{\text {th }}$ minute, $30^{\text {th }}$ minute, $1^{\text {st }}$ hour, $6^{\text {th }}$ hour, $24^{\text {th }}$ hour, and at every nurse visit afterwards routinely. The pain scores within the first 24 hours were included in our study.

Pain scores of 4 and higher are considered moderate pain and pain scores higher than 7, severe pain. All patients who had a pain score of 4 and higher received $1 \mathrm{mg} / \mathrm{kg}$ of intramuscular meperidine as rescue analgesic. The same nurse at the recovery unit and ward assessed pain scores and administered the analgesics. Also the nurse was blind to patient groups.

The patients were monitored for drug-related side effects (nausea, vomiting, hypotension, allergic reactions and respiratory depression) post-operatively. On the post-operative first day, the children were evaluated by a kidney-ureter-bladder radiography for residual fragments and place of the nephrostomy catheter. At the third post-operative day, the nephrostomy tube was removed under fluoroscopy in all patients. The patients were 
discharged after leakage at the tract site stoped. At the end of the first day, the parents were asked about their satisfactions with their child's pain management in the post-operative first 24 hours. Parents's satisfaction was assessed by a 5-point Likert scale ( $1=$ poor to $5=$ excellent).

\section{Statistical Analysis}

The results of our study were analyzed using the SPSS version 23.0. Chi-square test was used to compare categorical data and the Mann-Whitney U test was used to compare groups with non normal distribution. A p value of less than 0.05 was considered statistically significant.

\section{Results}

There was no significant difference in age, stone size, stone number, operative time, postoperative hospital stay, blood transfusion rate and drug-related side effects between LA and control groups (Table 1).

Nausea, vomiting and hypotension were the side effects. Hypotension was observed in only one patient who was in the control group and needed two doses of meperidine. All of our patients were clinically stone-free after PCNL (complete or with a residual stone smaller that $3 \mathrm{~mm}$ ).

Although pain scores at the first 15 minutes were higher in control group, statistical analysis showed no significant difference in FLACC and FPS scores between the two groups at 15 minutes, 30 minutes, 1 hour and 6 hours post-operatively. FLACC and FPS scores at post-operative $24^{\text {th }}$ hour were significantly lower in LA group than in controls ( $p=0.023, p=0.038$ respectively, Table 2 ). There was no significant difference in the number of patients who had severe pain between the groups (control group $n=6, L A$ group $n=5, p=0.726$ ).

We observed that post-operative pain was felt more in the first 15 minutes after PCNL as the pain scores were higher $(p=0.034)$. Pain after PCNL was found to be decreasing in time but the rate of decrease in LA group was distinctive. The analysis of the rate of decline in FLACC scores through post-operative $15^{\text {th }}$ minute, $30^{\text {th }}$ minute, $1^{\text {st }}$ hour, $6^{\text {th }}$ hour, and $24^{\text {th }}$ hour revealed that in the control group, FLACC scores decreased in the first hour where in LA group FLACC scores kept decreasing significantly also in the further $6^{\text {th }}$ and $24^{\text {th }}$ hour evaluations.

Twelve out of $21(57.1 \%)$ children in LA group and 18 out of 21

Table 1. Medians of patients' age, stone size, stone number, operation time, post-operative hospital stay and blood transfusion rate

\begin{tabular}{|c|c|c|c|}
\hline & Control group & LA group & p \\
\hline $\begin{array}{l}\text { Age, months } \\
\text { (median, min-max) }\end{array}$ & 60 (21-204) & 59 (9-204) & $0.320^{\mathrm{a}}$ \\
\hline $\begin{array}{l}\text { Stone Size, mm } \\
\text { (median, min-max) }\end{array}$ & $18(9-36)$ & $17(10-40)$ & $0.930^{a}$ \\
\hline $\begin{array}{l}\text { Stone number, } \mathrm{n} \\
\text { (median, min-max) }\end{array}$ & $2(1-7)$ & $2(1-7)$ & $0.240^{\mathrm{a}}$ \\
\hline $\begin{array}{l}\text { Operation time, minutes } \\
\text { (median, min-max) }\end{array}$ & $120(60-180)$ & $120(60-130)$ & $0.355^{a}$ \\
\hline $\begin{array}{l}\text { Postoperative hospital stay, } \\
\text { days (median, min-max) }\end{array}$ & $5(4-7)$ & $5(4-7)$ & $0.360^{\mathrm{a}}$ \\
\hline $\begin{array}{l}\text { Blood transfusion } \\
\text { (positive/negative) }\end{array}$ & $3 / 18$ & $3 / 18$ & $1.000^{b}$ \\
\hline
\end{tabular}

aMann-Whitney U test, ${ }^{b}$ Chi-square

Table 2. Face, legs, activity, cry and consolability scale score medians at $15^{\text {th }}$ minute, $30^{\text {th }}$ minute, $1^{\text {st }}$ hour, $6^{\text {th }}$ hour and $24^{\text {th }}$ hour post-operatively

\begin{tabular}{llll}
\hline & $\begin{array}{l}\text { Control group } \\
\text { (median, min-max) }\end{array}$ & $\begin{array}{l}\text { LA group } \\
\text { (median, min-max) }\end{array}$ & $\begin{array}{l}\text { p } \\
\text { (Mann-Whitney U test) }\end{array}$ \\
\hline 15 minutes FLACC score & $4(0-10)$ & $2(0-8)$ & 0.065 \\
\hline 30 minutes FLACC score & $2(0-8)$ & $2(0-8)$ & 0.295 \\
\hline 1 hour FLACC score & $2(0-6)$ & $2(0-5)$ & 0.481 \\
\hline 6 hours FLACC score & $1(0-5)$ & $0(0-3)$ & 0.091 \\
\hline 24 hours FLACC score & $0(0-5)$ & $0(0-2)$ & 0.023 \\
\hline
\end{tabular}

FLACC: Face, legs, activity, cry and consolability scale, LA: Local anesthetic, min: Minimum, max: Maksimum 
Table 3. The need for rescue analgesic in groups

\begin{tabular}{lll}
\hline Rescue analgesic administration & $\begin{array}{l}\text { Control group } \\
(\mathbf{n})\end{array}$ & $\begin{array}{l}\text { LA group } \\
(\mathbf{n})\end{array}$ \\
\hline None & 3 & 9 \\
\hline Just one dosage needed & 13 & 12 \\
\hline Second dosage needed & 5 & 0 \\
\hline Total number of dosage administered & $23(13+2 \times 5)$ & 12 \\
\hline LA: Local anesthetic & &
\end{tabular}

(85.7\%) children in control group needed rescue analgesic. The LA group needed significantly less rescue analgesia $(p=0.040)$. The patients in our study required rescue analgesic up to two doses at most. In control group, 13 patients needed one dose and 5 patients needed 2 doses of meperidine. Meperidine was administered in 12 patients once and second dose was not needed in LA group. The total number of analgesic requirement was significantly lower in LA patients compared to that in controls [12 doses and 23 doses, respectively $(p=0.018)]$. The need for second dose rescue analgesic was significantly higher in control group ( $p=0.017$ ) (Table 3 ).

Parents' satisfaction with their child's post-operative pain management was found to be significantly higher in LA group $(p=0.002)$. The median of satisfaction score in LA group was 4 (2-5) and the median in control group was 3 (1-5).

\section{Discussion}

Despite being a minimally-invasive surgery, PCNL is not pain-free due to the procedure itself and the presence of postoperative diversion. Pediatric PCNL has evolved from adult size instruments to Micro-PCNL in time. It has been reported that the use of smaller access sheaths was associated with less complication and less post-operative pain $(8,9,10,11)$. A study on patients with 1-2 cm stones, mini-PCNL and standard PCNL showed same stone-free rates where mini-PCNL was found to be advantageous in terms of analgesic requirement, hemoglobin drop and hospital stay (11).

Also, tubeless and totally tubeless PCNL were developed in order to reduce post-operative pain. In a retrospective study on 1469 patients, who underwent PCNL, the subjects were divided into three groups. In the first group, a $14 \mathrm{~F}$ nephrostomy catheter was placed, the second group received ureteral catheter and the third group received double J stent. In the nephrostomy group the length of hospital stay, need for blood transfusion, postoperative narcotic analgesic requirement and the complication rates were higher than in other groups (12). A study comparing tubeless PCNL with PCNL with a $14 \mathrm{~F}$ malecot catheter revealed that the tubeless group had shorter hospital stay, decreased NSAIDs requirement and decreased narcotic analgesic need (13). Tubeless PCNL and pain in pediatric age group was also studied. A study on 54 children undergoing PCNL in 60 renal units showed that children who underwent tubeless PCNL had less pethidine requirement and shorter hospital stay than $16 \mathrm{~F}$ nephrostomy group (14). Despite the different PCNL techniques described, indications for tubeless surgery are limited and not applicable for every case. Therefore, placing a nephrostomy tube for drainage after PCNL is the standard practice. A nephrostomy tube is the safest way of good drainage, managing bleeding and allowing second-look procedures. We aimed to evaluate the efficacy of LA infiltration in a standard pediatric PCNL patient. Our results showed that the FLACC scores in LA group were lower than in controls in all evaluation times though reaching statistical significance at postoperative $24^{\text {th }}$ hour.

Preemptive analgesia is the easiest and the safest way of managing surgical pain. However, the modern understanding of postoperative analgesia starts with sufficient intra-operative pre-emptive analgesia with regional or caudal blockade followed by balanced analgesia (15). Pre-emptive analgesia is an important concept that aims to induce the suppression of pain before neural hypersensitisation occurs (16). LAs or non-steroidal analgesics are given intra-operatively to delay post-operative pain and to decrease post-operative analgesic consumption. A LA administered before surgery may help preventing the adverse effects of NSAIDs and narcotic analgesics because it reduces the need for additional analgesic drugs (3). Bupivacaine infiltration before surgical incision is recommended by the American Society of Anesthesiologists because it has been shown to reduce post-operative pain scores (17). We prefer prilocaine and bupivacaine combination as LAs in our daily practice. Prilocaine is a short-acting LA where bupivacaine is a long-acting agent effective for 4-8 hours (18). In our study, pain scores after PCNL were highest in the first 15 minutes. Pietrow et al. (19) reported that patients with a $10 \mathrm{~F}$ nephrostomy tube placed after PCNL had lower post-operative pain scores than patients with $22 \mathrm{~F}$ tube. Also they found that pain scores were similar between the two groups at 6 hours post-operatively (19). Regarding the duration of analgesic effects of the drugs and the pain intensity after PCNL, we can postulate that especially bupivacaine is the suitable LA for preemptive analgesia in PCNL. In this study, we observed no severe analgesic-related side effects. Only nausea, vomiting and hypotension were observed and we found no significant difference between the groups. Our study revealed that the need for and total number of rescue analgesic was significantly less in LA group with no difference in drug-related side effects. This finding supports the logic of preemptive analgesia and favors the use of LA infiltration in children in terms of decreasing post-operative analgesic need.

Application of LA in adult PCNL patients has also been studied. In their randomized controlled study including 60 adult PCNL patients, Gokten et al. (4) used levobupivacaine as preemptive 
LA (4). They evaluated the patients post-operatively at the $6^{\text {th }}$ and $24^{\text {th }}$ hour with a visual analogue scale (VAS) and they used meperidine as rescue analgesic. The data showed that preemptive LA use in PCNL provided lower VAS scores, less amount and frequency of opioid use, less opioid-related side effects, higher satisfaction with analgesia, and early mobilization postoperatively. Parikh et al. (5) conducted a study on adult patients and preferred bupivacaine as LA after PCNL (5). They reported that in bupivacaine group, VAS scores and analgesic requirement were significantly lower. In another study, $10 \mathrm{~mL}$ of bupivacaine was infiltrated around nephrostomy tube in 53 adults during PCNL. They stated that peritubal LA infiltration was effective in reducing post-operative pain after PCNL even with supra-costal access (20). Likewise, the adult studies revealing a better selfreported analgesia satisfaction, our study -although depending on parental observation in some patients- also supports better postoperative analgesic satisfaction in LA group $(4,5)$.

We use the FLACC scale primarily for pain scoring in children because we believe that the FLACC scale provides more objective measurement of pain than VAS. Since the FLACC scale is applicable in all age groups (from newborns to adults), it is recommended by many authors as a reliable pain assessment tool in children after surgery (21).

The former studies on the preemptive use of LAs in PCNL were all conducted in adults. Our study is the first in the literature demonstrating the effects and safety of preemptive LA use in pediatric PCNL patients. We assume that the results of our study may provide guidance for further studies assessing and manipulating post-operative pain in children.

\section{Study Limitations}

This study is not without limitations. The limited number of patients may be the main cause of statistical indifference in the early pain evaluation despite the lower scores in the LA group. The efficacy of the protocol could be compared in different diversion (14 F vs $8 \mathrm{~F}$ nephrostomy vs tubeless) or instrument size (pediatric PCNL vs mini-PCNL vs micro-PCNL) groups.

These kinds of studies need very large number of patients with multi-institutional collaboration.

\section{Conclusion}

In pediatric PCNL, preemptive use of LA infiltration reduces postoperative pain, need for analgesics and number of analgesics used, in addition, improves patient's comfort and satisfaction with pain management with no increased drugrelated side effects. These results support that routine use of LA seems beneficial also in children as we promote LA use in our daily practice.

\section{Disclosure of Interest}

The authors declare no conflict of interest including specific financial interests or relationships and affiliations relevant to the subject matter or materials discussed in the manuscript. The authors have no ethical conflicts to disclose.

Presented in: $14^{\text {th }}$ Turkish Child Urology Congress.

\section{Ethics}

Ethics Committee Approval: The study were approved by the Hacettepe University Ethics Committee (protocol number: G017/122-19.

Informed Consent: Informed consent form was filled out by all participants.

Peer-review: Externally peer-reviewed.

\section{Authorship Contributions}

Concept: E.C., H.S.D., Ö.C., A.A.Y., S.T., Design: E.C., H.S.D., Ö.C., A.A.Y., S.T., Data Collection and/or Processing: E.C., F.I., A.C.B., H..S.D., Analysis and/or Interpretation: E.C., A.C.B., H.S.D., S.T., Literature Research: E.C., H.S.D., Ö.C., A.A.Y., S.T., Writing: E.C., H.S.D., A.A.Y., S.T.

Conflict of Interest: No conflict of interest was declared by the authors.

Financial Disclosure: The authors declared that this study received no financial support.

\section{References}

1. Ganpule AP, Bhattu AS, Desai M. PCNL in the twenty-first century: role of Microperc, Miniperc, and Ultraminiperc. World J Urol 2015;33:235-240.

2. Istanbulluoglu MO, Cicek T, Ozturk B, Gonen M, Ozkardes H. Percutaneous nephrolithotomy: nephrostomy or tubeless or totally tubeless? Urology 2010;75:1043-1046.

3. Kaufman $E_{1}$ Epstein JB, Gorsky $M$, Jackson DL, Kadari A. Preemptive analgesia and local anesthesia as a supplement to general anesthesia: a review. Anesth Prog 2005;52:29-38.

4. Gokten $\mathrm{OE}$, Kilicarslan $\mathrm{H}$, Dogan HS, Turker G, Kordan Y. Efficacy of levobupivacaine infiltration to nephrosthomy tract in combination with intravenous paracetamol on postoperative analgesia in percutaneous nephrolithotomy patients. J Endourol 2011;25:35-39.

5. Parikh GP, Shah VR, Modi MP, Chauhan NC. The analgesic efficacy of peritubal infiltration of $0.25 \%$ bupivacaine in percutaneous nephrolithotomy-- a prospective randomized study. J Anaesthesiol Clin Pharmacol 2011;27:481-484.

6. Jaskowski SK. The FLACC: A behavioral scale for scoring postoperative pain in young children. AACN Nursing Scan In Critical Care 1998;8:16.

7. Ochi JW. Acupuncture instead of codeine for tonsillectomy pain in children Int J Pediatr Otorhinolaryngology 2013;77:2058-2062.

8. Bilen CY, Koçak B, Kıtırcı G, Özkaya O, Sarıkaya S. Percutaneous nephrolithotomy in children: lessons learned in 5 years at a single institution. J Urol 2007;177:1867-1871.

9. Yamaguchi A, SkolarikosA, BuchholzNP,Chomón GB, Grasso M, Saba P, Nakada $\mathrm{S}$, de la Rosette J; Clinical Research Office Of The EndourologicalSociety 
Percutaneous Nephrolithotomy Study Group. Operating times and bleeding complications in percutaneous nephrolithotomy: a comparison of tract dilation methods in 5537 patients in the Clinical Research Office of the Endourological Society Percutaneous Nephrolithotomy Global Study. J Endourol 2011;25:933-939.

10. Knoll T, Wezel F, Michel MS, Honeck P, Wendt-Nordahl G. Do patients benefit from miniaturized tubeless percutaneous nephrolithotomy? A comparative prospective study. J Endourol 2010;24:1075-1079.

11. Mishra S, Sharma R, Garg C, Kurien A, Sabnis R, Desai M. Prospective comparative study of miniperc and standard PNL for treatment of 1 to $2 \mathrm{~cm}$ size renal stone. BJU Int 2011;108:896-900.

12. Gonulalan U, Cicek $T$, Istanbulluoglu 0 , Kosan $M$, Ozturk B, Ozkardes $H$. Tubeless percutaneous nephrolithotomy is effective and safe in short-and long-term urinary drainage. Urolithiasis 2013;41:341-346.

13. Istanbulluoglu MO, Ozturk B, Gonen M, Cicek T, Ozkardes H. Effectiveness of totally tubeless percutaneous nephrolithotomy in selected patients: a prospective randomized study. Int Urol Nephrol 2009;41:541-545.

14. Samad L, Zaidi Z. Tubed vs tubeless PCNL in children. J Pak Med Assoc 2012;62:892-896

15. C. Radmayr (Chair), G. Bogaert, H.S. Dogan, R. Kočvara, J.M. Nijman (Vicechair), R. Stein ST, L.A. 't Hoen, J. Quaedackers, M.S. Silay, Undre S. EAU guidelines on pediatric urology. Management of postoperative pain. EAU Annual Congress. Copenhagen 2018: EAU Guidelines Office, Arnhem, The
Netherlands. http://uroweb.org/guidelines/compilations-of-all-guidelines/: 2018.

16. Woolf CJ, Chong MS. Preemptive analgesia--treating postoperative pain by preventing the establishment of central sensitization. Anesth Analg 1993;77:362-379.

17. American Society of Anesthesiologists Task Force on Acute Pain Management. Practice Guidelines for Acute Pain Management in the Perioperative Setting An Updated Report by the American Society of Anesthesiologists Task Force on Acute Pain Management. Anesthesiology 2012;116:248-273.

18. Morgan GE, Mackey DC, Wasnick JD, Mikhail MS, Murray MJ, Butterworth J. Morgan \&t Mikhail's Clinical Anesthesiology Fifth Edition, Vol 1, Fifth Edition ed. McGraw-hill New York, 2013.

19. Pietrow PK, Auge BK, Lallas CD, Santa-Cruz RW, Newman GE, Albala DM, Preminger GM. Pain after percutaneous nephrolithotomy: impact of nephrostomy tube size. J Endourol 2003;17:411-414.

20. Lojanapiwat B, Chureemas T, Kittirattarakarn P. The efficacy of peritubal analgesic infiltration in postoperative pain following percutaneous nephrolithotomy-A prospective randomized controlled study. Int Braz J Urol 2015;41:945-952.

21. von Baeyer CL, Spagrud L. Systematic review of observational (behavioral) measures of pain for children and adolescents aged 3 to 18 years. Pain 2007;127:140-150. 